\title{
PREDATION BY THE NONNATIVE RAINBOW TROUT, ONCORHYNCHUS MYKISS (WALBAUM, 1792), ON THE NATIVE BIOTA FROM FRESHWATER ENVIRONMENT OF THE CENTRAL ANDES (ARGENTINA)
}

* Instituto de Medicina y Biología Experimental de Cuyo, CCT Mendoza-CONICET, Z. C. 330 Mendoza, Argentina, AR-5500, jmriosrama@gmail.com, ORCID 0000-0001-7018-1458.

KEYWORDS: Andes, Oncorhynchus mykiss, rainbow trout, predation, native biota.

\section{ABSTRACT}

This study aimed to examine the impact of the nonnative rainbow trout Oncorhynchus mykiss on the native biota that inhabits freshwater environments of the central Andes, Argentina. To assess the predation pressure on native Andean vertebrates and invertebrates, the stomach contents were taken from rainbow trout caught at three Andean sites. Results showed that the major prey items were the native torrent catfish Hatcheria macraei (100\% in diet), Elmidae coleopterans (23\%), and the native crab Aegla affinis (38\%) in the rainbow trout stomachs collected from Cipolletti Dam (North zone), Yaucha River (Middle zone), and Vaina Stream (South zone), respectively. This preliminary study exhibits the predation pressure of the rainbow trout on native Andean species and suggests that policies are necessary to control the release of fry of this exotic salmonid in the Andes region.

RESUMEN: Depredación de la trucha arcoíris, Oncorhynchus mykiss, sobre la biota nativa de ambientes de agua dulce de los Andes centrales (Argentina).

Este estudio tuvo como objetivo examinar el impacto de la trucha arcoíris, Oncorhynchus mykiss, sobre la biota nativa que habita en ambientes de agua dulce de los Andes centrales, Argentina. Para abordar esto, se tomó el contenido estomacal de truchas arcoíris capturadas en tres sitios para evaluar la presión de depredación sobre los vertebrados e invertebrados andinos nativos. Los resultados mostraron que las principales presas fueron el bagre nativo Hatcheria macraei (100\% en la dieta), los coleópteros Elmidae (23\%) y el cangrejo nativo Aegla affinis (38\%) presente en los estómagos de las truchas arcoíris capturadas en el dique Cipolletti (zona Norte), el Río Yaucha (zona Intermedia) y el Arroyo Vaina (zona Sur), respectivamente. Este estudio preliminar muestra la presión de depredación de la trucha arcoíris sobre las especies nativas andinas y sugiere que se apliquen políticas de control para la liberación de alevines de este salmónido exótico en Andes centrales.

REZUMAT: Prădătorismul păstrăvului curcubeu non-nativ, Oncorhynchus mykiss, asupra biotei native din mediul dulcicol din Anzii centrali (Argentina).

Acest studiu a avut ca scop examinarea impactului păstrăvului curcubeu non-nativ Oncorhynchus mykiss asupra biotei native care populează mediile dulcicole din Anzii centrali, Argentina. Pentru atingerea acestui scop, a fost prelevat conținutul stomacal de la indivizii de păstrăv curcubeu capturați în trei situri andine pentru a evalua presiunea de prădător asupra vertebratelor și nevertebratelor andine native. Rezultatele au arătat că principalele specii pradă au fost somnul nativ Hatcheria macraei (100\% în dietă), coleoptere din familia Elmidae (23\%) și crabul nativ Aegla affinis (38\%) găsite în stomacurile indivizilor de păstrăv curcubeu colectați de la barajul Cipolletti (zona de nord), râul Yaucha (zona de mijloc) și respectiv pârâul Vaina (zona de sud). Acest studiu preliminar prezintă presiunea de prădător a păstrăvului curcubeu asupra speciilor native andine și sugerează că sunt necesare reglementări pentru a controla eliberarea alevinilor acestui salmonid exotic în Anzii Centrali. 


\section{INTRODUCTION}

Invasive fish species continue to be a leading threat to the structure and function of aquatic ecosystems worldwide (Rypel, 2014; Gubiani et al., 2018). In addition to their inherent negative impacts on native fauna, the monetary cost of invasive species across six developed nations is an estimated 335 billion US dollars per year (Rypel, 2014). Significant emphasis has been placed on predicting invasions and understanding why certain invasive species are successful (Lusk et al., 2010). According to the literature, the irrational introduction of exotic fish species usually produces strong ecological imbalances, due to the lack of specific predators in the aquatic environment (Lusk et al., 2010; Rypel, 2014; Gubiani et al., 2018).

The ichthyofauna of the Andes fits perfectly into this general pattern, since the phenotypic plasticity and voracity of salmonids, especially rainbow trout Oncorhynchus mykiss (Walbaum, 1792), allows them to quickly adapt and colonize new environments. The rainbow trout are thus able to displace native species through predation and competitive exclusion (Figueroa et al., 2010; Zarco et al. 2020).

Along the river basins of the central Andes region in Argentina, the rainbow trout, a fish species native to North America, has been successfully introduced due to its recreational and gastronomic relevance (Ríos et al., 2019). This salmonid is a voracious top predator fish (Alvear et al., 2007; Di Prinzio et al., 2013; Ríos et al., 2015), considered as one of the 100 most harmful invasive exotic species in the world (Global Invasive Species Database, 2020). It is known that fry mainly feed on invertebrates that occupy low levels of the food web (Molineri, 2008), while adult trout incorporate other fish, amphibians and macrocrustaceans into their diet (Alvear et al., 2007; Di Prinzio et al., 2013; Ríos et al., 2015). This potentially negative impact on the native biota, identifies the rainbow trout as an invasive fish that could cause pernicious and irreversible consequences on the biodiversity of the central Andes' freshwater environments. Furthermore, given the migratory behaviour of these salmonids, they may reach areas where rainbow trout were previously absent and thus increase the detrimental effect on native populations (Zarco et al., 2020).

Rainbow trout, a well known competitor for food for native fishes around the world (McLennan and MacMillan, 1984; Lucas, 2008; Kruzhylina and Didenko, 2011) were initially introduced to the Mendoza Province in the central Andes region, Argentina, in 1957 (Villanueva and Roig, 1995). The tasks of official introduction of this salmonid coming from San Carlos de Bariloche (Argentinean Patagonia) to Mendoza were carried out through procedures made in the hatchery El Manzano (Villanueva and Roig, 1995), located in the middle zone of the central Andes region. Specifically, these procedures include incubating, rearing, and stocking fry. Since 1957 to date, release of fry takes place regularly in several rivers and streams within the Mendoza Province of the central Andes (Secretaria de Ambiente, 2013).

This study aimed to examine the potential impact of the nonnative rainbow trout on the native Andean biota and assessed the plausible implications for the biodiversity of freshwater environments of the central Andes region. Due to the sampling limitations (e.g., difficult access to high elevation mountain sites), the sample sizes in this study were relatively low. However, our results add new information to the scarce data on the effect of a voracious predator on native freshwater biota and can be taken as an indicative baseline for the central Andes region. 


\section{MATERIAL AND METHODS}

Georeferenced sampling sites, the number of individuals captured, and the fish morphometry of rainbow trout are detailed in table 1. The captures were made in freshwater environments corresponding to the North, Middle and South zones of the central Andes region. All fish specimens were adults and caught during the Austral autumn (April to June) in 2014 by using conventional fishing with artificial lures according to our research authorization (permission issued by the Direction of Renewable Natural Resources of the Government of Mendoza, research permit \#659). Immediately after capture and sacrifice, fish were transported in coolers with ice to the laboratory, where the specimens were weighed $(0.01 \mathrm{~g})$ and sized before dissection. The length of the fish was measured from the front-tip of the mouth to the end of the caudal fin (total length).

Table 1: Sampling sites and fish morphometry of rainbow trout (Oncorhynchus mykiss) from central Andes.

\begin{tabular}{|c|c|c|c|c|c|c|c|}
\hline Sites & Zone & Latitude & Longitude & $\begin{array}{c}\text { Altitude } \\
(\text { m.a.s.l. })\end{array}$ & N & $\begin{array}{c}\text { Total weight } \\
(\mathrm{g})\end{array}$ & $\begin{array}{c}\text { Total length } \\
(\mathrm{cm})\end{array}$ \\
\hline $\begin{array}{c}\text { Cipolletti } \\
\text { Dam }\end{array}$ & North & -33.0519 & 68.9396 & 1009 & 3 & $335 \pm 20.2$ & $28.7 \pm 0.75$ \\
\hline $\begin{array}{c}\text { Yaucha } \\
\text { River }\end{array}$ & Middle & -34.2458 & 69.3260 & 1873 & 6 & $198 \pm 6.81$ & $25.7 \pm 0.42$ \\
\hline $\begin{array}{c}\text { Vaina } \\
\text { Stream }\end{array}$ & South & -35.9329 & 70.0419 & 1689 & 7 & $282 \pm 22.8$ & $27.8 \pm 0.90$ \\
\hline
\end{tabular}

Specifically, the rainbow trout were caught in the Cipolletti Dam $(n=3)$ belonging to the Mendoza River basin (North zone), in the Yaucha River $(n=6)$ of the Tunuyán River basin (Middle zone), and in the Vaina Stream $(\mathrm{n}=7)$ belonging to the Rio Grande basin (South zone). Because rainbow trout and the native torrent catfish Hatcheria macraei, (Trichomycteridae) (Girard, 1855) are sympatric species in the Mendoza River basin (Villanueva and Roig, 1995), several specimens of $H$. macraei were collected from the Cipolletti Dam, to morphologically compare them with the semi-digested fish found in the stomachs of the three rainbow trout caught from this site. This procedure allowed a correct taxonomic classification.

The dissection of each specimen was performed with a scalpel and surgical scissors. The content of the excised stomachs was conserved in ethanol:water (70:30) individually for each specimen for the subsequent identification of the prey items. All the fish detailed here were processed and conditioned in the same way prior to the diet analysis. The contents of each stomach were examined in the Entomology Laboratory of IADIZA (Argentine Institute for Arid Zones Research) by using a binocular magnifying glass and systematic keys (Domínguez and Fernández, 2009). The arthropods and fish present were taxonomically identified and the diet was estimated according to the study site. The occurrence of each item consumed by each individual was calculated, differentiating by site. The quantity of each prey item present in the individualized stomachs of the trout was expressed as the percentage of said prey item in relation to the total number of prey contained in each stomach. 


\section{RESULTS AND DISCUSSION}

The analysis of the stomachs of the rainbow trout from the Cipolletti Dam (North zone), showed that $100 \%$ of the diet was composed only by the native fish species Hatcheria macraei (Fig. 1).

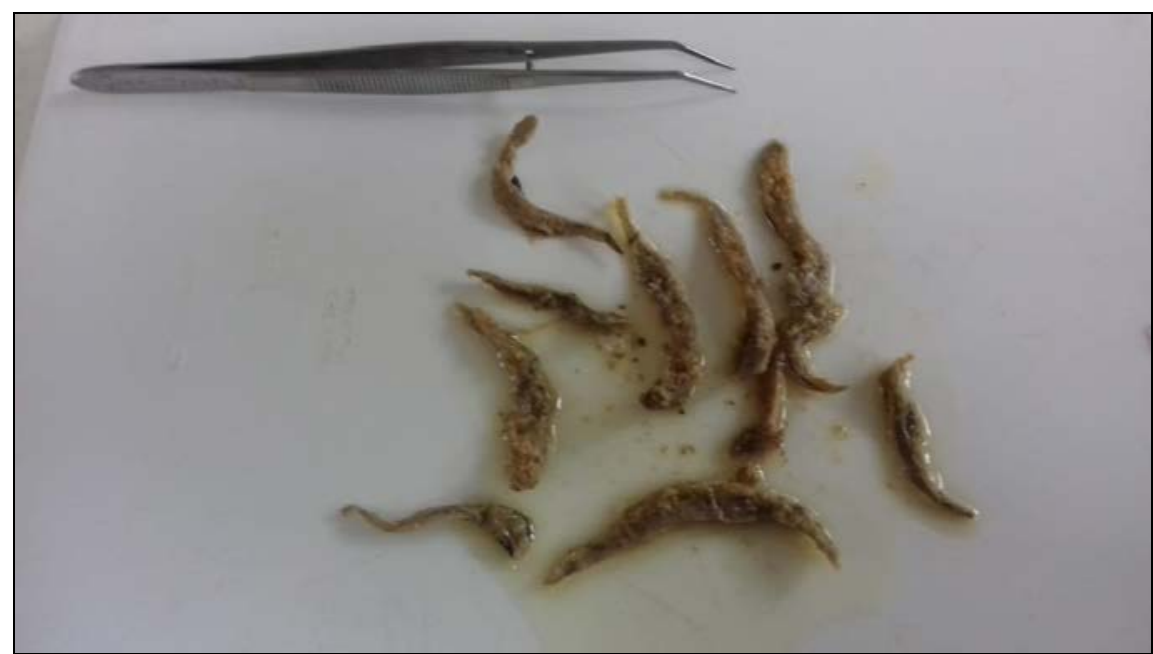

Figure 1: Stomach content of rainbow trout $(\mathrm{n}=3)$ from Cipolletti Dam. The three stomachs analyzed contained only the native fish Hatcheria macraei (100\% in diet).

The stomachs of the Yaucha River (Middle zone) trout contained a great diversity of food items, however, the dominant prey (23\%) were the beetles of the Elmidae family (Fig. 2).

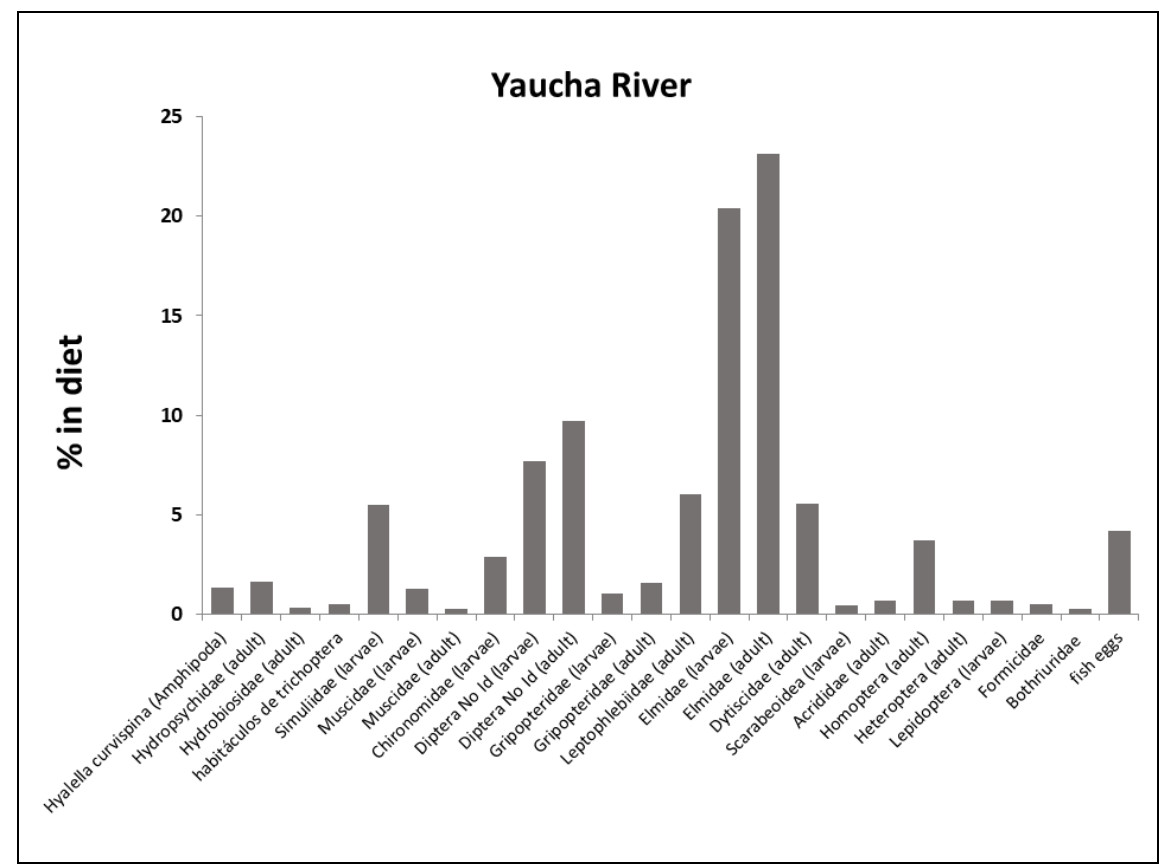

Figure 2: Food items in the stomachs of rainbow trout $(n=6)$ from the Yaucha River.

The trout from Vaina Stream (South zone), contained 38\% of the river crab Aegla affinis Schmitt, 1942 in their stomachs, being their major prey item (Fig. 3). 


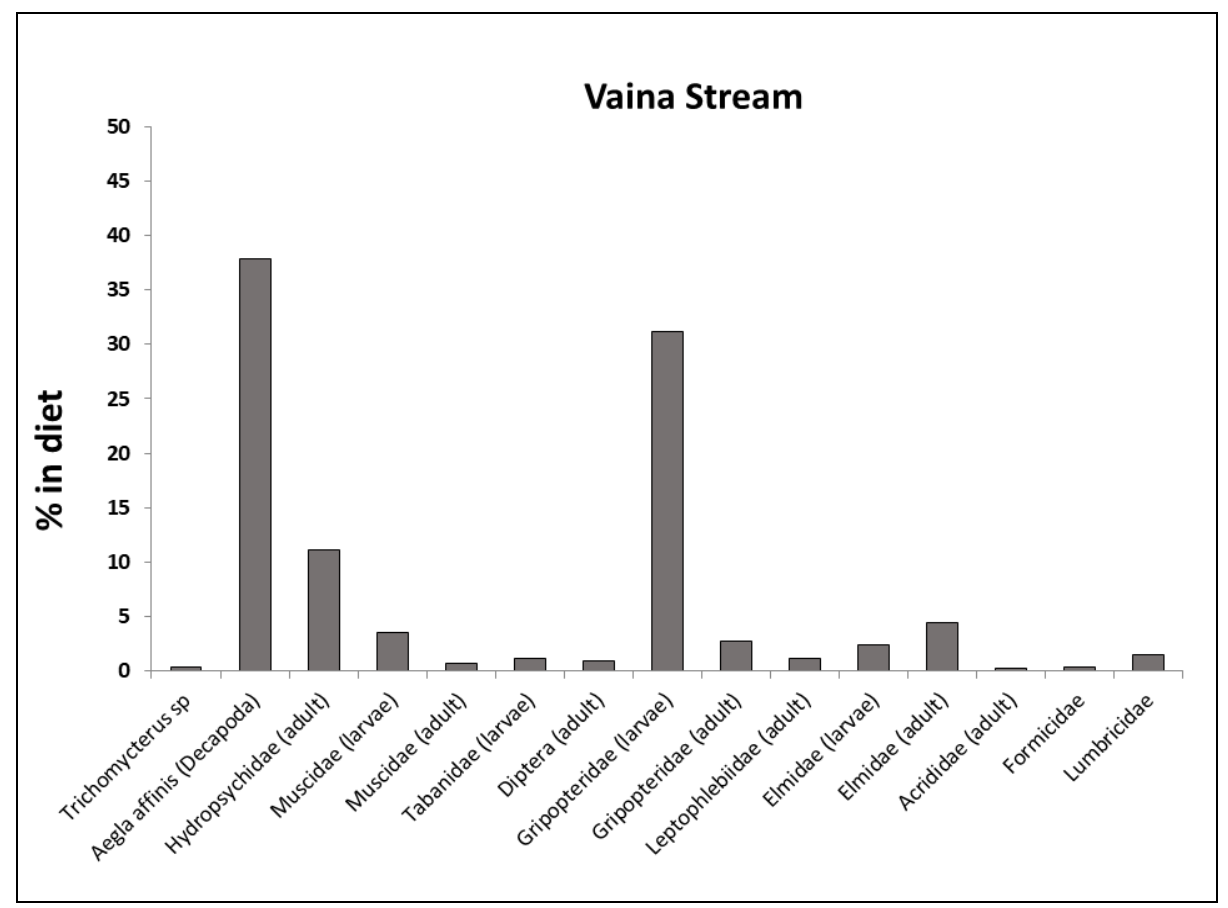

Figure 3: Food items in the stomachs of rainbow trout $(n=7)$ from Vaina Stream.

\section{CONCLUSIONS}

This preliminary study showed the negative impact of an exotic fish on native biota such as the fish Hatcheria macraei and the river crab Aegla affinis Schmitt, 1942 from the central Andes region.

The synergistic effects of introducing an exotic predator with previous stressors are unknown, but could be detrimental to native fish populations, amphibians (Zarco et al., 2020), as well as macrocrustaceans (Vigliano et al., 2009). Recently, Zarco et al. (2020) reported for the first time, the predation of rainbow trout on the critically endangered Pehuenche Spinychest Frog Alsodes pehuenche Cei, 1976, an endemic species from the central Andes region, highlighting an additional factor in the decline of populations of this frog species.

Critical actions are necessary to prevent the entrance of rainbow trout into rivers and streams where trout are still absent, and to avoid an increase in trout density in the freshwater environments of the central Andes region. Policies are needed to control the culture and release of trout in Andean rivers and streams.

\section{ACKNOWLEDGEMENTS}

This study was supported by Consejo Nacional de Investigaciones Científicas y Técnicas (CONICET), Agencia Nacional de Promoción Científica y Tecnológica [ANPCyT PICT 2016:0093]. A special thanks to Juan Gabriel Ríos, Héctor Garde and Hugo Pacheco for their help in the field. Dedicated to the lovely memory of Raúl Ríos (1948-2020) for having instructed me in the art of mountain fishing.

\section{REFERENCES}

1. Alvear P. A., Rechencq M., Macchi P. J., Alonso M. F., Lippolt G. E., Denegri M. A. and Vigliano P. H., 2007 - Composición, distribución y relaciones tróficas de la ictiofauna del río Negro, Patagonia Argentina, Ecología Austral, 17, 231-246. (in Spanish) 
2. Di Prinzio C. Y., Miserendino M. L. and Casaux R., 2013 - Feeding strategy of the non-native rainbow trout, Oncorhynchus mykiss, in low-order Patagonian streams, Fisheries Management and Ecology, 20, 414-425.

3. Domínguez E. and Fernández H. R., 2009 - Macroinvertebrados bentónicos sudamericanos. Sistemática y biología, Fundación Miguel Lillo, Tucumán, Argentina, 656. (in Spanish)

4. Figueroa R., Ruiz V. H., Berrios P., Palma A., Villegas P. and Andreu-Soler A., 2010 - Trophic ecology of native and introduced fish species from the Chillán River, South-Central Chile, Journal of Applied Ichthyology, 26, 1, 78-83.

5. Global Invasive Species Database, 2020 - Species profile: Oncorhynchus mykiss, available at: http://www.iucngisd.org/gisd/species.php?sc=103.

6. Gubiani E. A., Ruaro R., Ribeiro V. R., Eichelberger A. C. A., Bogoni R. F., Lira A. D. and Da Graca W. J., 2018 - Non-native fish species in Neotropical freshwaters: how did they arrive, and where did they come from?. Hydrobiologia, 817, 1, 57-69.

7. Kruzhylina S. and Didenko A., 2011 - Autumn diet and trophic relations of juvenile brown trout (Salmo trutta), Rainbow Trout (Onchorhynchus mykiss) and European Grayling (Thymallus thymallus) in the Shipot River (Ukraine), Transylvanian Review of Systematical and Ecological Research, 11, The Upper Tisa River Basin, 169-182.

8. Lucas M. C., 2008 - Food interrelationships between brown trout, Salmo trutta L., and rainbow trout, Oncorhynchus mykiss (Walbaum), in a small put-and-take stillwater fishery, Aquaculture Research, 24, 3, 355-364.

9. Lusk S., Lusková V. and Hanel L., 2010 - Alien fish species in the Czech Republic and their impact on the native fish fauna, Journal of Vertebrate Biology, 59, 1, 57-72.

8. McLennan J. A. and MacMillan B. W. H., 1984 - The food of rainbow and brown trout in the Mohaka and other rivers of Hawke's Bay, New Zealand, New Zealand Journal of Marine and Freshwater Research, 18, 143-158.

9. Molineri C., 2008 - Impact of rainbow trout on aquatic invertebrate communities in subtropical mountain streams of northwest Argentina, Ecología Austral, 18, 101-117.

10. Ríos J. M., Lana N. B., Berton P., Ciocco N. F. and Altamirano J. C., 2015 - Use of wild trout for PBDE assessment in freshwater environments, Emerging Contaminants, 1, 54-63.

11. Ríos J. M., Ruggeri M. F., Poma G., Malarvannan G., Covaci A., Puliafito S. E. and Altamirano J. C., 2019 - Occurrence of organochlorine compounds in fish from freshwater environments of the central Andes, Argentina, Science of the Total Environment, 693, 133389.

12. Rypel A. L., 2014 - Do invasive freshwater fish species grow better when they are invasive? Oikos, 123, 3, 279-289.

13. Secretaría de Ambiente, 2013 - Gobierno de Mendoza. Programa de reproducción y siembra de salmónidos, access 21/11/2020: https://www.mendoza.gov.ar/prensa/ambiente-presento-elprograma-de-reproduccion-y-siembra-de-peces/.

14. Vigliano P. H., Beauchamp D. A., Milano D., Macchi P. J., Alonso M. F., Asorey M. I. G. and Barriga J. P., 2009 - Quantifying predation on galaxiids and other native organisms by introduced rainbow trout in an ultraoligotrophic lake in northern Patagonia a bioenergetics modeling approach, Transactions of the American Fisheries Society, 138, 1405-1419.

15. Villanueva M. and Roig V., 1995 - La ictiofauna de Mendoza, Reseña histórica, introducción y efectos de especies exóticas, Multequina, 4, 93-104. (in Spanish)

16. Alvear P. A., Rechencq M., Macchi P. J., Alonso M. F., Lippolt G. E., Denegri M. A. and Vigliano P. H., 2007 - Composición, distribución y relaciones tróficas de la ictiofauna del río Negro, Patagonia Argentina, Ecología Austral, 17, 231-246. (in Spanish)

17. Di Prinzio C. Y., Miserendino M. L. and Casaux R., 2013 - Feeding strategy of the non-native rainbow trout, Oncorhynchus mykiss, in low-order Patagonian streams, Fisheries Management and Ecology, 20, 414-425.

18. Zarco A., Corbalán, V. and Debandi G., 2020 - Predation by invasive rainbow trout on the critically endangered Pehuenche Spiny-chest Frog, Journal of Fish Biology, https://doi.org/10.1111/jfb.14609. 